\title{
Arbuscular mycorrhizal fungi and auxin associated with microelements in the development of cuttings of Varronia leucocephala
}

\author{
Mônica D. S. da S. Fernades ${ }^{1}$, Marciana B. de Morais ${ }^{1}$, Francisco F. Mesquita-Oliveira ${ }^{1}$, \\ Cláudia Ulisses ${ }^{2}$, José F. de Medeiros ${ }^{3} \&$ Cynthia C. de Albuquerque ${ }^{1}$
}

\footnotetext{
${ }^{1}$ Universidade do Estado do Rio Grande do Norte/Programa de Pós-Graduação em Ciências Naturais. Mossoró, RN, Brasil. E-mail: monica.dani22@hotmail.com - ORCID: 0000-0002-2129-4154; marciana.bio@gmail.com (Corresponding author) - ORCID: 0000-0001-5074-5244: ffabiomesquita@gmail.com - ORCID: 00000001-8191-1532; cycavalcanti@gmail.com - ORCID: 0000-0002-0959-1404

${ }^{2}$ Universidade Federal Rural de Pernambuco/Programa de Pós-Graduação em Botânica. Recife, PE, Brasil. E-mail: claulisses@gmail.com - ORCID: 0000-0001-9723-5057

${ }^{3}$ Universidade Federal Rural do Semi-Árido/Programa de Pós-Graduação em Fitotecnia. Mossoró, RN, Brasil. E-mail: jfrancismar.rn@uol.com.br ORCID: 0000-0003-1202-8783
}

\begin{abstract}
The plant Varronia leucocephala is widely used in Brazil for its therapeutic properties. However, a major problem for the seedlings is the low percentage of root formation. The objective of this study was to establish a rooting protocol for $V$. leucocephala cuttings, using phytoregulators and microelements associated with arbuscular mycorrhizal fungi. The auxin indole-3-butyric acid (IBA) concentration of $1500 \mathrm{mg} \mathrm{L}^{-1}$ showed the best rooting percentage, and it is proposed associating the microelements zinc and boron with the highest IBA doses. Although an increase in the rooting percentage was observed in the presence of zinc, it was not the most suitable for improving the percentage of propagation. Consequently, association of arbuscular mycorrhizal fungi with $1500 \mathrm{mg} \mathrm{L}^{-1} \mathrm{IBA}$ plus zinc was selected to evaluate the rooting percentage and sprouting of the aerial part, dry biomass of roots and aerial part, number of leaves, height, mycorrhizal colonization and dependency, spore density, and nutrients of branches and roots. These results show that using zinc with the highest doses of IBA $\left(1500 \mathrm{mg} \mathrm{L}^{-1}\right)$ in plants inoculated with the arbuscular mycorrhizal fungus (Gigaspora albida) was the most effective at promoting the vegetative propagation of V. leucocephala.
\end{abstract}

Key words: boron, rooting, zinc

\section{Micorrizas arbusculares e auxinas associadas com microelementos no desenvolvimento de estacas de Varronia leucocephala}

RESUMO: Varronia leucocephala é uma planta utilizada pela população para fins terapêuticos. Um dos maiores problemas para produção de mudas dessa espécie é o baixo percentual de enraizamento. Objetivou-se estabelecer um protocolo de enraizamento de estacas de $V$. leucocephala utilizando fitorreguladores e microelementos associados com fungos micorrízicos arbusculares. Sendo a concentração de $1500 \mathrm{mg} \mathrm{L}^{-1}$ do ácido indolbutírico (AIB) a que proporcionou maior percentual de enraizamento, propôs-se associar os microelementos zinco (Zn) e boro (B) com maiores concentrações de AIB. Na presença do Zn, observou-se incremento na percentagem de enraizamento; no entanto, não foi o ideal para aumentar a percentagem de propagação. Testou-se a associação de fungos micorrízicos arbusculares junto à concentração de $1500 \mathrm{mg} \mathrm{L}^{-1}$ de AIB para avaliar o percentual de enraizamento e brotação de parte aérea; biomassa seca de raiz e parte aérea; número de folhas; altura; colonização e dependência micorrízica; densidade de esporos e nutrientes da parte aérea e da raiz. A utilização de zinco juntamente a doses mais elevadas de AIB (1500 $\left.\mathrm{mg} \mathrm{L}^{-1}\right)$ e associada com fungo micorrízico arbusculares (Gigaspora albida) tornaram-se eficientes para a propagação vegetativa de V. leucocephala.

Palavras-chave: boro, enraizamento, zinco 


\section{INTRODUCTION}

Medicinal plants are widely used in Brazil, but studies aimed at establishing rational conservation and management schemes for many species are scarce. Establishing strategies for the supply of the raw material for commercial exploitation is needed to avoid extractivism and reduce the risk of extinction facing several plant species (Maciel, 2010).

Varronia leucocephala (Moric.) J.S.Mill. is prominent among species with medicinal potential. This species, which belongs to the family Boraginaceae, is endemic to the Caatinga biome and can be found mainly in the brazilian states Piauí, Ceará, Paraíba, Pernambuco, and Bahia (Melo, 2015). Several parts of the plant have been widely used in popular medicine (Abrantes \& Agra, 2004), including the bark and flowers that are used for rheumatism, indigestion, hemorrhages, throat inflammation, and arthritis (Castro \& Cavalcante, 2011). In addition, studies with roots that revealed anticancer activity demonstrate the potential of this plant (Marinho-Filho et al., 2010). Due to the its medicinal importance and intensive use, the development of a seedling production technique is necessary since vegetative propagation by cuttings is difficult with this species, likely due to intrinsic factors.

Indole-3-butyric acid (IBA) is one of the most effective and widely used auxins for vegetative shoot production by cuttings, exhibiting low toxicity, low mobility, and high chemical stability (Hartmann et al., 2011). In addition, boron and zinc are considered to be active cofactors in the rooting of cuttings. Also contributing to the development of cuttings is the use of arbuscular mycorrhizal fungi (AMF). However, studies evaluating the relationship between mycorrhizal fungi and cuttings treated with auxins and microelements are still scarce. In this context, the present study aimed to establish a rooting protocol for cuttings of $V$. leucocephala using phytoregulators and microelements associated with AMF.

\section{Material AND Methods}

The study was carried out at the State University of Rio Grande do Norte (UERN), in a greenhouse protected with a white sombrite mesh with $30 \%$ attenuation of solar radiation. During the experimental period, the average temperature in the greenhouse was $35.9^{\circ} \mathrm{C}$ and the relative humidity was $68.4 \%$. The soil used in the experiment was collected from the same place where the studied species is present $\left(5^{\circ} 12^{\prime} 10^{\prime \prime} \mathrm{S}\right.$ and $37^{\circ} 18^{\prime} 57^{\prime \prime} \mathrm{W}$ ) in the municipality of Mossoró/RN. Different experiments were conducted to establish a protocol for largescale propagation of the species.

\section{Experiment 1}

The bases of the cuttings were immersed for $10 \mathrm{~min}$ in solutions with different concentrations of the auxin IBA (1.5, 15,150 , and $1500 \mathrm{mg} \mathrm{L}^{-1}$ ), containing $100 \mathrm{mg} \mathrm{L}^{-1}$ boron or zinc. For comparison, a control treatment without auxins or mineral elements was also evaluated. After exposure, the cuttings were planted in 8-L capacity recipients containing the substrate (natural soil + humus, in a ratio of $3: 1)$. The experiment was conducted in a completely randomized design, in a $4 \times 2+1$ factorial scheme ( 4 concentrations of auxin $\times 2$ mineral elements + control), making a total of nine treatments with five replicates, with three cuttings for each repetition. For the control treatment, the cuttings were immersed in water and the time of immersion was the same as for the other treatments. The number of shoots was quantified at the end of the experiment and the rooting percentage was evaluated.

\section{Experiment 2}

Inocula of the mycorrhizal fungi Acaulospora longula, Gigaspora albida, Glomus clarum, and Claroideoglomus etunicatum were obtained from the Federal Rural University of Pernambuco (UFRPE). They were multiplied in sand previously sterilized in an autoclave $\left(121^{\circ} \mathrm{C}, 1\right.$ atm for $1 \mathrm{~h}$, then dried in a forced circulation oven at $70{ }^{\circ} \mathrm{C}$ for 2 days) mixed with Vermiculite Expanded ${ }^{\oplus}$. In the greenhouse, this mixture was distributed in recipients in which seeds of Panicum milaceum (Millet), a plant used as host for the AMF, were planted for germination. The substrate used in the experiment was a mixture of the collected soil and humus in a 3:1 ratio, and the substrate was autoclaved at $121^{\circ} \mathrm{C}$ with $1 \mathrm{~atm}$ pressure for $1 \mathrm{~h}$ to completely remove any microorganisms. After sterilization, the soil was dried for 2 days in a forced circulation oven at $70^{\circ} \mathrm{C}$. After preparation, the substrates were characterized according to their physical and chemical characteristics (EMBRAPA, 1997) (Table 1).

In this experiment, $V$. leucocephala cuttings were collected as previously described, and were treated with IBA at a

Table 1. Physical and chemical characteristics of untreated and treated substrates (Treatment 1, without inoculum; Treatment 2, containing Acaulospora longula inoculum; Treatment 3, containing Gigaspora albida inoculum; Treatment 4, containing Glomus clarum inoculum; Treatment 5, containing Claroideoglomus etunicatum inoculum)

\begin{tabular}{|c|c|c|c|c|c|c|}
\hline \multirow[b]{2}{*}{ Attributes } & \multicolumn{6}{|c|}{ Substrate } \\
\hline & $\begin{array}{c}\text { Natural } \\
\text { soil }\end{array}$ & T1 & T2 & T3 & T4 & T5 \\
\hline Texture & Sand & Sand & Sand & Sand & Sand & Sand \\
\hline Silt (\%) & 4.7 & 6.23 & 7.8 & 8.14 & 8.54 & 3.58 \\
\hline Clay (\%) & 0.78 & 1.54 & 1.8 & 2.47 & 2.15 & 0.32 \\
\hline Sand (\%) & 94.51 & 92.05 & 90.3 & 88.42 & 88.98 & 95.64 \\
\hline $\mathrm{DA}\left(\mathrm{g} \mathrm{cm}^{3}\right)$ & 1.53 & 1.56 & 1.48 & 1.47 & 1.53 & 1.51 \\
\hline ST (ppt) & 198.4 & 196.2 & 204 & 201 & 198.01 & 204 \\
\hline TSD (ppt) & 194.8 & 188.0 & 201 & 197.3 & 202.9 & 212.41 \\
\hline$N\left(g^{-1}\right)$ & 3.01 & 4.62 & 2.17 & 1.75 & 1.68 & 2.38 \\
\hline $\mathrm{pH}\left(\mathrm{H}_{2} \mathrm{O}\right)$ & 7.70 & 7.30 & 7.50 & 7.00 & 7.50 & 7.40 \\
\hline $\mathrm{OM}\left(\mathrm{g} \mathrm{kg}^{-1}\right)$ & 20.98 & 17.20 & 18.61 & 19.45 & 19.32 & 21.20 \\
\hline $\mathrm{P}\left(\mathrm{mg} \mathrm{dm^{-3 }}\right)$ & 273.6 & 32.8 & 37.1 & 241.6 & 220.2 & 242.2 \\
\hline $\mathrm{K}^{+}\left(\mathrm{mg} \mathrm{dm}^{-3}\right)$ & 157.8 & 549.7 & 221.7 & 286.4 & 296.5 & 821.3 \\
\hline $\mathrm{Na}^{+}\left(\mathrm{mg} \mathrm{dm} \mathrm{dm}^{-3}\right)$ & 209.0 & 137.1 & 139.0 & 404.1 & 323.3 & 1009.9 \\
\hline $\mathrm{Ca}^{2+}\left(\mathrm{cmol}_{\mathrm{c}} \mathrm{dm}^{-3}\right)$ & 8.40 & 7.40 & 7.00 & 7.60 & 8.60 & 8.90 \\
\hline $\mathrm{Mg}^{2+}\left(\mathrm{cmol}_{\mathrm{c}} \mathrm{dm}^{-3}\right)$ & 0.80 & 2.50 & 2.20 & 4.10 & 1.70 & 2.40 \\
\hline $\mathrm{Al}^{3+}\left(\mathrm{cmol}_{\mathrm{c}} \mathrm{dm}^{-3}\right)$ & 0.00 & 0.00 & 0.00 & 0.00 & 0.00 & 0.00 \\
\hline $\mathrm{Cu}\left(\mathrm{mg} \mathrm{dm}^{-3}\right)$ & 0.31 & 0.36 & 0.37 & 1.27 & 0.90 & 0.75 \\
\hline $\mathrm{Fe}\left(\mathrm{mg} \mathrm{dm}^{-3}\right)$ & 13.8 & 23.4 & 21.9 & 45.3 & 44.3 & 48.7 \\
\hline $\operatorname{Mn}\left(\mathrm{mg} \mathrm{dm}^{-3}\right)$ & 62.7 & 87.4 & 80.3 & 29.3 & 32.9 & 30.7 \\
\hline $\mathrm{Zn}\left(\mathrm{mg} \mathrm{dm}^{-3}\right)$ & 25.13 & 37.89 & 37.59 & 15.47 & 15.10 & 18.17 \\
\hline $\mathrm{H}^{+} \mathrm{Al}\left(\mathrm{cmol}_{\mathrm{c}} \mathrm{dm}^{-3}\right)$ & 0.00 & 0.00 & 0.00 & 0.33 & 0.00 & 0.00 \\
\hline $\mathrm{SB}\left(\mathrm{cmol}_{\mathrm{c}} \mathrm{dm}^{-3}\right)$ & 10.51 & 11.90 & 10.37 & 14.19 & 12.46 & 17.79 \\
\hline $\mathrm{t}\left(\mathrm{cmol}_{\mathrm{c}} \mathrm{dm}^{-3}\right)$ & 10.51 & 11.90 & 10.37 & 14.19 & 12.46 & 17.79 \\
\hline CTC $\left(\mathrm{cmol}_{\mathrm{c}} \mathrm{dm}^{-3}\right)$ & 10.51 & 11.90 & 10.37 & 14.52 & 12.46 & 17.79 \\
\hline$V(\%)$ & 100 & 100 & 100 & 98 & 100 & 100 \\
\hline m (\%) & 0 & 0 & 0 & 0 & 0 & 0 \\
\hline PST (\%) & 9 & 5 & 6 & 12 & 11 & 25 \\
\hline
\end{tabular}

The $\mathrm{pH}$ in water was determined in the soil / water ratio of 1:2,5. EC - Electrical conductivity of the soil / water extract in the 1:2,5. The elements $\mathrm{P} \mathrm{Na}^{+}$and $\mathrm{K}^{+}$were extracted according with Mehlich-1 in the 1:10 ratio (soil/soil). The $\mathrm{Ca}^{2+}, \mathrm{Mg}^{2+}$, and $\mathrm{Al}^{3+}$, were extracted with $1 \mathrm{~mol} \mathrm{~L}^{-1} \mathrm{KCl}$ in the ratio 1:10 (soil/extractor). ( $\left.\mathrm{H}+\mathrm{Al}\right)$ - Potential acidity extracted with calcium acetate $0.5 \mathrm{moL} \mathrm{L}^{-1}$ in the ratio 1:15 (soil/extractor). SB - Sum of bases. $t$ - CTC effective. CTC the soil or CTC a pH 7.0. V - Base Saturation. $\mathrm{m}$ - Aluminum saturation. PST - Percentage of exchangeable sodium. Total salinity (ST). Total dissolved solids (STD) and apparent density. 
concentration of $1500+100 \mathrm{mg} \mathrm{L}^{-1}$ zinc for $10 \mathrm{~min}$. The cuttings were cultivated in 8 -L capacity polyethylene recipients containing a substrate of natural soil + humus in a 3:1 ratio, and inoculated with a mixture of inoculum soil containing approximately 200 spores + hyphae + colonized roots of Acaulospora longula, Gigaspora albida, Glomus clarum, or Claroideoglomus etunicatum, constituting treatments T2, T3, T4, and T5, respectively. For the control treatment (T1), the cuttings were planted in recipients containing only the substrate (without AMF). The plants were grown under greenhouse conditions and irrigated daily to maintain soil moisture.

The experiment lasted 72 days and the number of shoots was quantified weekly. The following variables were evaluated at the end of the experiment: height $(\mathrm{cm})$ of a previously selected branch, which was measured between the insertion site of the cutting base and the apical meristem, using a tape measure; dry mass of the aerial part (DMAP) and of the root (RDM), quantified after drying the material in an incubator with forced circulation and air renovation at $70{ }^{\circ} \mathrm{C}$ until constant mass; root-aerial part ratio (R/AP); rooting percentage; and number of leaves counted at the end of the experiment. The sum of DMAP and RDM determined the total dry mass (DMtotal). From DMtotal, the mycorrhizal dependence (MD) was determined according to the following formula:

$$
\mathrm{MD}=100 \times\left[\frac{(\mathrm{A}-\mathrm{B})}{\mathrm{A}}\right]
$$

where:

A - represents the dry mass of the mycorrhizal plants;

B - dry mass of the non-mycorrhized plants (Planchette et al., 1983).

To evaluate the percentage of mycorrhizal colonization, the methodology described by Phillips \& Hayman (1970) was used, with some modifications. The colonization rate was estimated by the blade method according to Giovanetti \& Mosse (1980). AMF spores were extracted by the wet sieving method described by Gerdemann \& Nicolson (1963). Subsequently, the sample was

A.

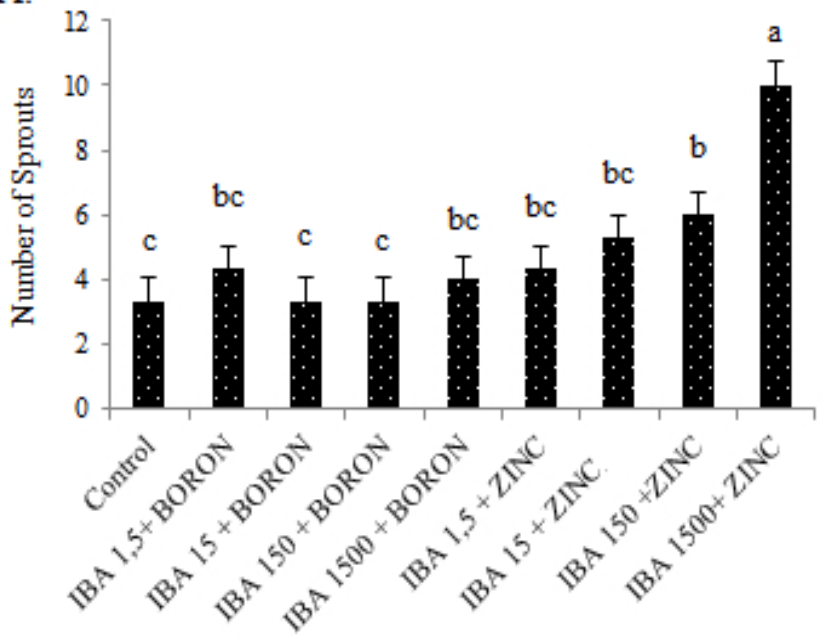

Means followed by the same lowercase letter do not differ by Tukey's test $(p \leq 0.01)$ centrifuged at $1106 \times \mathrm{g}$ for $5 \mathrm{~min}$. Then, a $50 \%$ sucrose solution was added to the precipitate and the material was centrifuged again at $1106 \times \mathrm{g}$ for $3 \mathrm{~min}$ (Jenkins, 1964). The supernatant was poured into a $0.053 \mu \mathrm{m}$ sieve; the retained material was washed with tap water to remove excess sucrose, and then transferred to a beaker and diluted with water to $50 \mathrm{~mL}$. From this volume, an aliquot of $0.5 \mathrm{~mL}$ was collected and observed under a stereomicroscope $(10 \times)$; the spores were then estimated per gram of soil used in each replicate (Malibari et al., 1988).

The content levels of N, P, K and Na were evaluated, with $\mathrm{P}, \mathrm{K}$, and $\mathrm{N}$ levels in the leaves and roots being determined by the wet digestion method, according to Plank (1992). The determination of $\mathrm{P}$ was based on the vanadate yellow method (EMBRAPA, 2000), and the quantification of $\mathrm{K}$ and $\mathrm{Na}$ was performed by flame spectrometry. The determination of total nitrogen followed the semi-micro Kjeldahl method (AOAC, 1990) and quantification was performed by spectrophotometry as described by Baethgen \& Alley (1989).

The experiment was carried out in a completely randomized design, comprising 5 treatments with 10 replicates each. The data were submitted to analysis of variance (ANOVA), and the means were compared using Tukey's test $(\mathrm{p} \leq 0.01)$ of significance. Statistical analysis was performed using Assistat ${ }^{\circledast}$ software, version 7.6 beta.

\section{Results AND Discussion}

\section{Experiment 1}

Varronia leucocephala exposed to increasing IBA concentrations with added zinc showed an increase in the percentage of rooted cuttings and number of sprouts. The concentration of $1500 \mathrm{mg} \mathrm{L}^{-1}$, with added zinc, produced an adventitious rooting stimulatory effect, while boron had no significant effect on rooting percentage or number of sprouts compared to zinc (Figures $1 \mathrm{~A}$ and $\mathrm{B}$ ).

Zinc is essential for adventitious rooting, playing an important role in optimizing IAA enzymatic oxidation, as well as regulating the endogenous levels of this auxin (Hartmann et al., 2011). The positive effect of zinc on the

B.

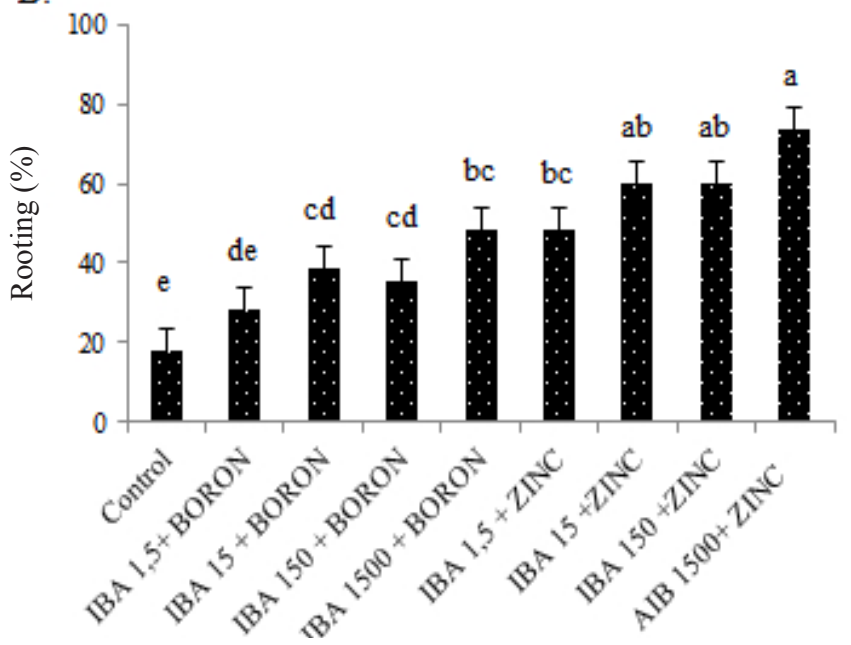

Figure 1. Average number of sprouts $(A)$ and rooting percentage $(B)$ of Varronia leucocephala treated with different concentrations of IBA $\left(1.5,15,150\right.$ and $\left.1500 \mathrm{mg} \mathrm{L}^{-1}\right)$ with added zinc or boron 
cuttings of $V$. leucocephala was due to the importance of this element in rhizogenesis, since this mineral acts as a stimulator of the biosynthesis of endogenous auxins, altering the auxin/cytokinin balance and resulting in a more significant production of auxiliary roots (Pacholczak et al., 2015). Notably, zinc is also required for the biosynthesis of tryptophan, an auxin precursor (Milléo \& Cristófoli, 2015).

\section{Experiment 2}

The DMAP, RDM, DMtotal, and R/AP relationship values showed a significant difference $(\mathrm{p} \leq 0.01)$ between the treatments. For G. albida and G. clarum, a 400\% increase in dry mass of the aerial part was recorded, significantly different to the control (Figure 2A), and the highest average for root growth was obtained with the cuttings inoculated with $G$. albida (3.5 $\mathrm{g} \mathrm{plant}^{-1}$ ) (Figure $2 \mathrm{~B}$ ). The reduction in the $\mathrm{R} /$ AP value shows that there was a greater investment in the aerial part of the plants with G. albida and G. clarum (Figure $2 \mathrm{C}$ ). The mycorrhizal association increased shoot and root production, and consequently the total dry mass (Figure 2D).

A.

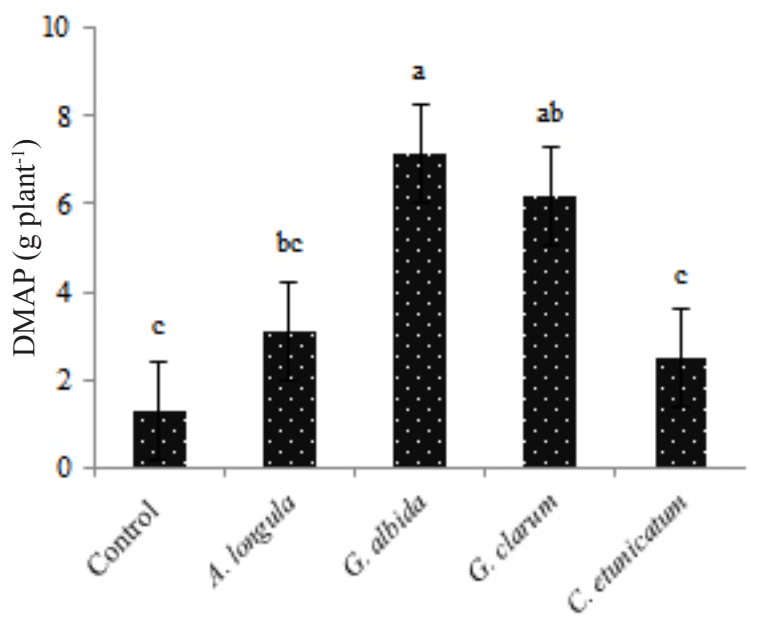

C.

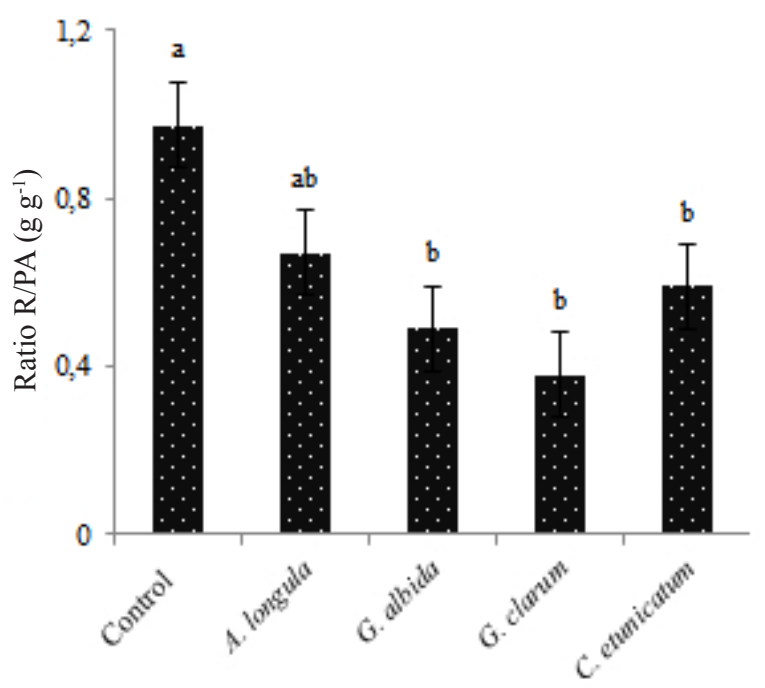

This indicates that the mycorrhizal fungi G. albida and G. clarum were efficient in promoting the development of aerial part of V. leucocephala.

The rooting percentage of cuttings treated with IBA (without AMF) was substantially lower compared to cuttings associated with AMF. This can be explained by the benefit provided by the AMF, since the cuttings can present rooting difficulties, even if treated with IBA (Figure 3A). However, the rooting capability increases when cuttings are inoculated with arbuscular mycorrhizal fungi (Amri, 2015). Therefore, the increase in root production observed with the mycorrhizal treatments may be related to the IBA treatment, since this phytoregulator can play a specific and direct role in establishing symbioses between fungi and plant roots, as well as stimulating the fungus to lateral root formation in the host (Etemadi et al., 2014). Once inside the root, the AMF develop highly branched structures, called arbuscules, within the cortical cells, that facilitate the transfer of nutrients to the plant. This suggests that the increase in total dry mass of $V$. leucocephala plants associated with AMF was due to the symbiosis between the roots of the host plants and the

B.

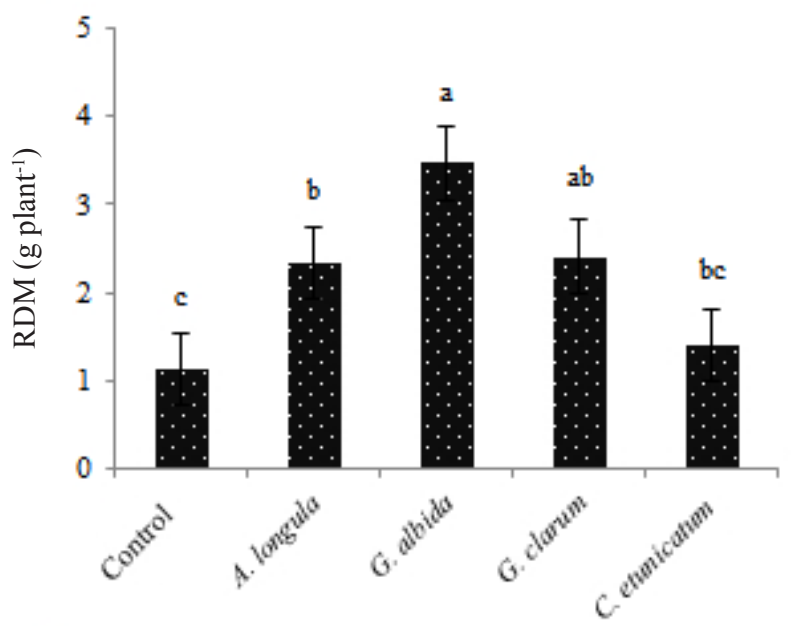

D.

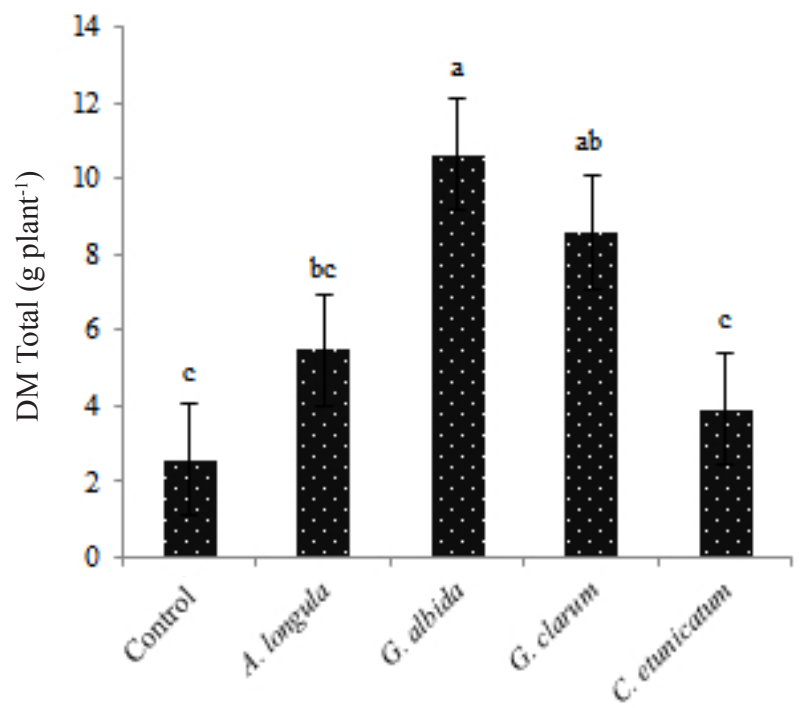

Means followed by the same lowercase letter do not differ by Tukey's test $(p \leq 0.01)$

Figure 2. Means of dry mass of the aerial part (A), root dry mass (B), root/aerial part ratio (C), and total dry mass (D) of Varronia leucocephala associated with the arbuscular mycorrhizal fungi (with AMF) Acaulospora longula, Gigaspora albida, Glomus clarum, and Claroideoglomus etunicatum, and control (without AMF) 
mycorrhizal fungi that resulted in an increase in nutrient and water absorption, thus favoring biomass production.

Despite plants inoculated with $C$. etunicatum showing the least developed aerial part, there was an increase in dry mass of the aerial part compared to the control (Figure 3C), confirming the efficacy of AMF for the vegetative development of $V$. leucocephala. Some studies have reported increased benefits for plants species, like angico plants, inoculated with more than one species of mycorrhizal fungus, with the plants exhibiting increased growth when inoculated with both Glomus etunicatum and Gigaspora albida (Sugai et al., 2011).

Compared to the control treatment, mycorrhizal association resulted in a significant difference $(\mathrm{p} \leq 0.01)$ in the rooting percentage, number of leaves, shoots, and height (Figure 3 ), confirming the benefit of the AMF association (Figure 3A). Moreover, the branches that sprouted from $V$. leucocephala cuttings grew more with G. albida inoculation (Figure 3D).

The number of leaves was higher in cuttings associated with AMF. This confirmed that the symbiosis between the roots of the host plant and the fungus (Figure 3B) provided

A.

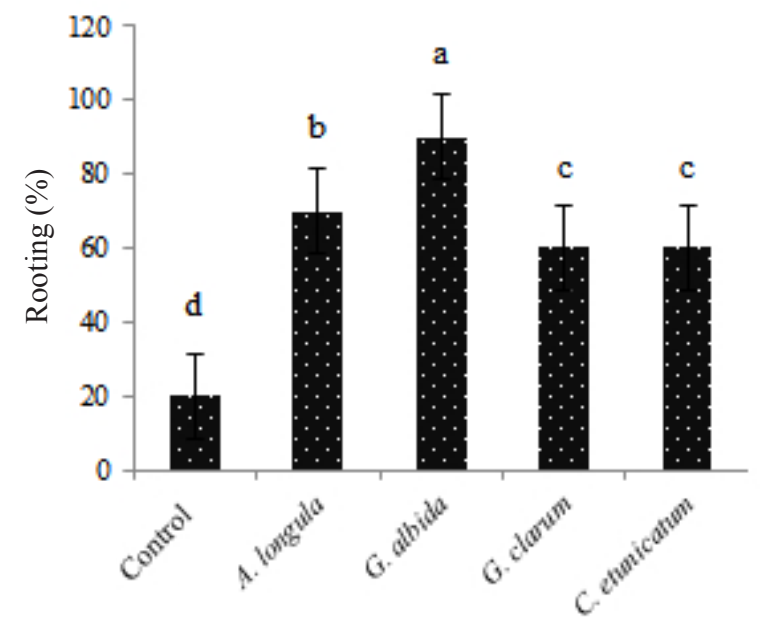

C.

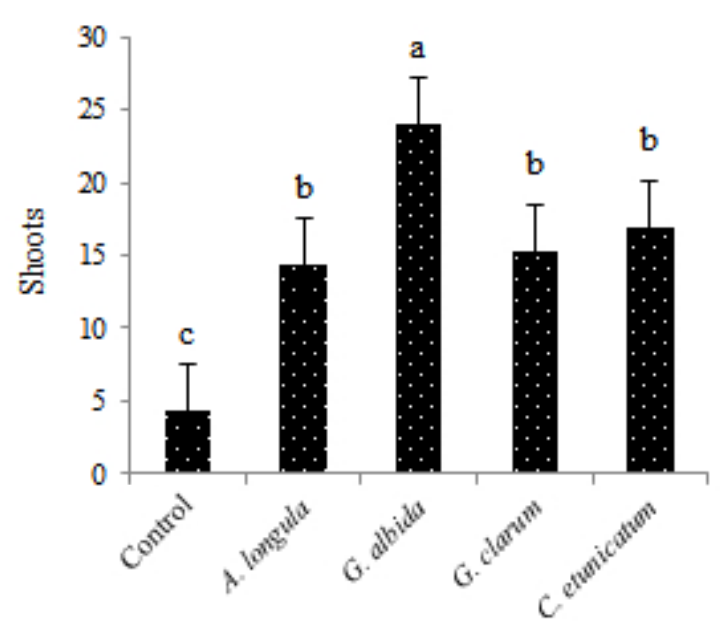

a greater absorption of mineral nutrients, allowing for a greater investment of metabolic energy in the production of shoot biomass. Studies with Robinia pseudoacacia showed that the number of leaves increased in plants inoculated with mycorrhizal fungi, even under water stress (Yang et al., 2014).

The percentage of root system colonization varied according to the inoculating fungus (Figure 4A) when spore numbers in the soil were high (Figure 4B). Evaluation of root colonization allowed the identification of some mycorrhizal structures (arbuscules, hyphae, vesicles, auxiliary cells, and hyphae) in the roots. This colonization was advantageous for the plants since the volume of the root system was enlarged, allowing increased nutrient absorption and favorable plant development.

The efficiency of some AMF species in relation to the tested host could be observed (Figure 4C), even though inoculation resulted in varied seedling growth. The efficiency of most AMF species evaluated in this study was significant; cuttings exhibited slow development with the control treatment (without inoculation), suggesting a possible dependence of this species on the mycorrhizal association.

B.

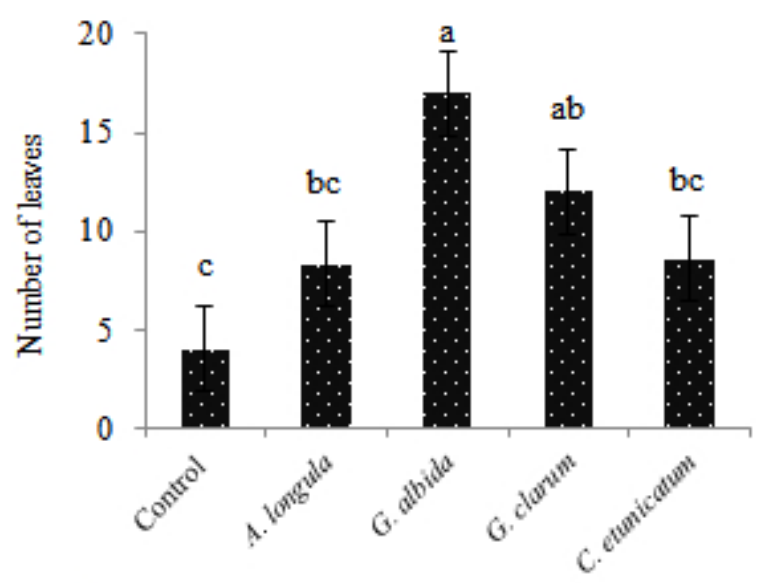

D.

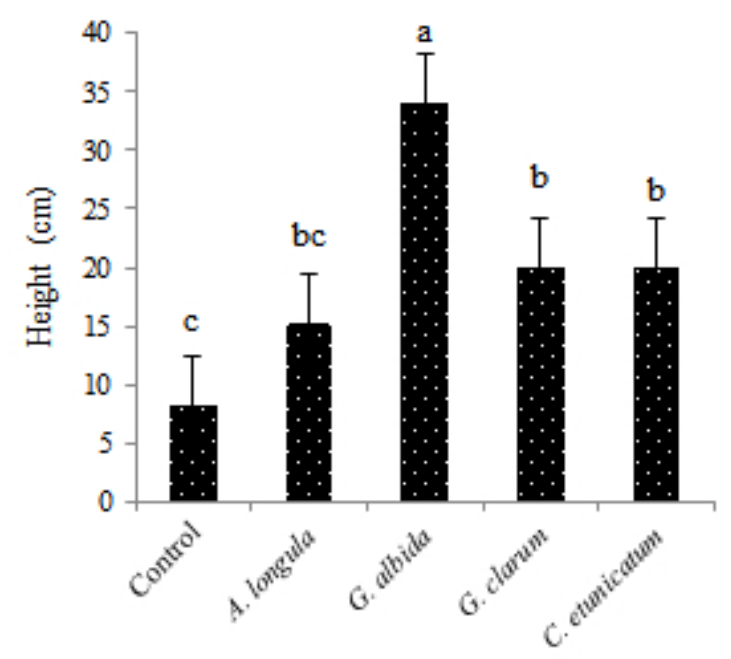

Means followed by the same lowercase letter do not differ by Tukey's test $(p \leq 0.01)$

Figure 3. Means of rooting percentage (A), number of leaves (B), shoots (C), and height (D) of Varronia leucocephala associated with the arbuscular mycorrhizal fungi (with AMF) Acaulospora longula, Gigaspora albida, Glomus clarum, and Claroideoglomus etunicatum, and control (without AMF) 
A.

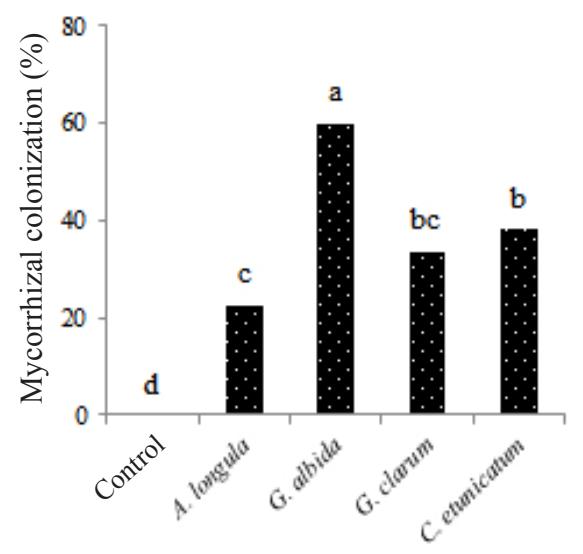

B.

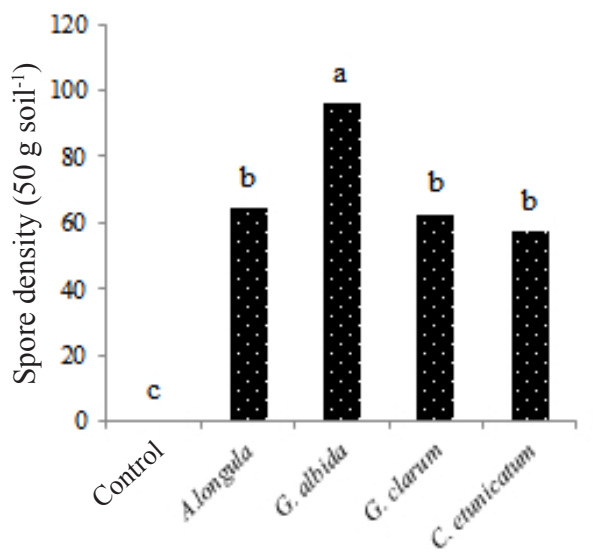

C.

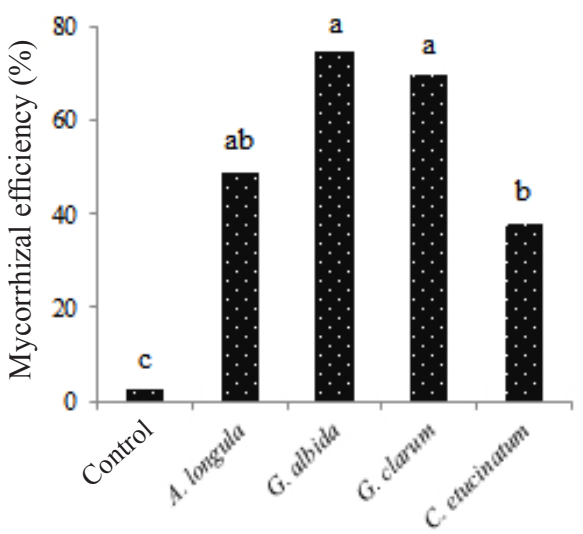

Means followed by the same lowercase letter do not differ by Tukey's test $(p \leq 0.01)$

Figure 4. Means of mycorrhizal colonization (A), spore density (B), and mycorrhizal efficiency (C) of Varronia leucocephala associated with the arbuscular mycorrhizal fungi (with AMF) Acaulospora longula, Gigaspora albida, Glomus clarum, and Claroideoglomus etunicatum, and control (without AMF)

Mycorrhizal colonization of the V. leucocephala species was more effective when associated with the fungus G. albida. These results corroborate the dry mass data of the aerial part, dry root mass, height, leaf number, shoots, and rooting percentage, confirming that this fungal species afforded the greatest increase in these variables. The increase in the development of the host plants resulted from increased nutrient absorption, particularly nutrients with low soil mobility like phosphorus, due to the development of internal structures in the roots and the extraradical hyphae that function as an extension of the root system, increasing the soil exploration area by more than one-hundred-fold (Balota et al., 2011). High mycorrhizal colonization of the roots of Amburana cearensis and Libidibia ferrea associated with G. albida was also shown to promote the development of these species (Silva et al., 2014; Oliveira et al., 2015).

There was no significant difference in nitrogen $(\mathrm{N})$ levels between the treatments in the aerial part. In the roots, a significant difference was observed with A. longula and $G$. clarum different to C. etunicatum inoculation (Figure 5A). There was no significant difference $(p<0.01)$ in $P$ levels observed in roots of plants associated with AMF (Figure 5B).

Physical-chemical analysis of the substrates (Table 1) demonstrates that $\mathrm{N}$ levels were lower with the AMF treatments. However, neither this low availability of $\mathrm{N}$ in the soil, nor the reduced $\mathrm{N}$ levels in the roots and plant aerial part, influenced the dry biomass content of the roots and aerial part in the plants. AMF may also be involved in the nitrogen cycle, indicating that $\mathrm{N}$ transfer to plants by AMF may be one benefit of AMF root colonization (Hodge \& Fitter, 2010). The requirement for $\mathrm{N}$ transportation via fungal hyphae depends on the demand for $\mathrm{N}$ in the plant (Johansen et al., 1994). This was evidenced in this study since the $\mathrm{N}$ content in the mycorrhizal-associated plants was not significantly different to the control (without AMF), although this element was strongly available in the soil.

The mutual symbiosis between the AMF and the plants is advantageous for both organisms, since the plants provide the fungi with energetic products resulting from photosynthesis,
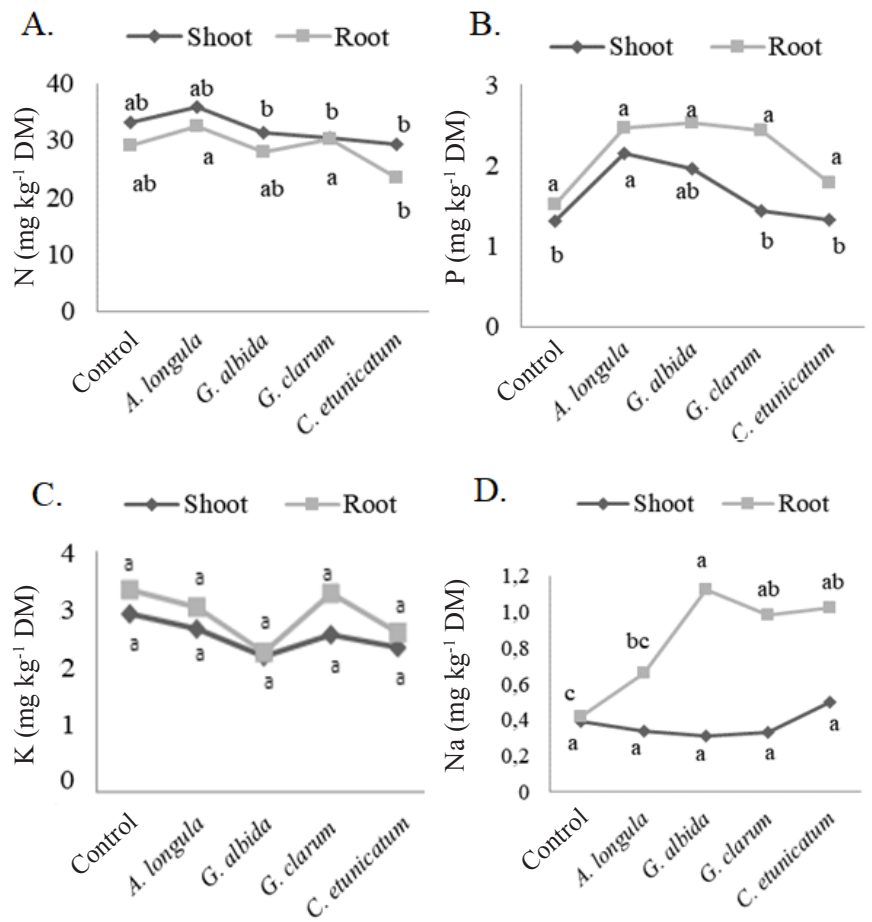

Means followed by the same lowercase letter do not differ by Tukey's test $(p<0.01)$; DM - dry mass

Figure 5. Nitrogen (A), phosphorus (B), sodium (C) and potassium (D) content of the root and the shoot of Varronia leucocephala plants associated with the arbuscular mycorrhizal fungi (with AMF) Acaulospora Iongula, Gigaspora albida, Glomus clarum, and Claroideoglomus etunicatum, and the control (without AMF)

allowing for growth and maintenance; for their part, the AMF provide the plant with water and nutrients such as phosphorus and nitrogen (Hodge \& Storer, 2014). Increased vegetal biomass increases nutrient demand by plants, and it was verified an increase in $\mathrm{P}$ content in the shoots only for A. logula treatment. Sheng et al. (2008) also observed an increase in P concentrations in mycorrhizal-associated plants, confirming that AMF colonization can increase the absorption of this element. Therefore, AMF inoculation can be an important tool for the development of Varronia leucocephala cuttings. High mycorrhizal colonization of the roots of Amburana cearensis 
and Libidibia ferrea associated with G. albida was also shown to promote the development of these species (Silva et al., 2014; Oliveira et al., 2015).

There was no significant difference in $\mathrm{K}^{+}$contents among the treatments, either in the roots or in the roots (Figure 5C). In contrast, the $\mathrm{Na}^{+}$concentration was higher in the aerial part of the plants inoculated with G. albida, G. clarum, and C. etunicatum in relation to control (Figure 5D). In the aerial part, the $\mathrm{Na}^{+}$levels were low in relation to the roots in all the treatments, indicating limited translocation of this element to the aerial part. Normally, plants are deficient in $\mathrm{K}^{+}$in soils with high levels of $\mathrm{Na}^{+}$. However, it was verified that although the $\mathrm{Na}^{+}$levels in the plants were higher with mycorrhizal treatments in the roots, the levels of $\mathrm{K}^{+}$did not differ significantly between treatments, inferring that the AMF stimulated $\mathrm{K}^{+}$absorption despite the high concentrations of $\mathrm{Na}^{+}$in the soil. Therefore, colonization by AMF can improve $\mathrm{K}^{+}$uptake in soils and prevent the transport of $\mathrm{Na}^{+}$to the aerial part, thus avoiding $\mathrm{Na}^{+}$induced saline stress (Talaat \& Shawky, 2011).

Notably, following the experimental phase, analysis of the soil (Table 1) showed an increase in $\mathrm{Na}^{+}$in the mycorrhizal substrates. With C. etunicatum and G. albida, the amount of $\mathrm{Na}^{+}$in the soil increased approximately two- and five-fold, respectively, relative to the natural soil treatment (before the experiment). The substrates presenting higher levels of $\mathrm{Na}^{+}$ (inoculated with C. etunicatum and G. albida) corresponded to the treatments showing decreased levels of $\mathrm{K}^{+}$in the tissues, although there was no significant difference between treatments in relation to $\mathrm{K}^{+}$.

The $\mathrm{Na}^{+}$detected in the soil (Table 1 ) was absorbed by the roots and, as seen in Figure 5, this element was more concentrated in the roots than the aerial part. The bioaccumulation factor evaluates the $\mathrm{Na}^{+}$accumulation efficiency of the plant in relation to the soil concentration and, although it was not the focus of this study, it was possible through this test to prove the potential for $\mathrm{Na}^{+}$bioaccumulation in V. leucocephala. The calculus of the bioaccumulation factor was higher than 1 for all treatments, showing that $\mathrm{Na}^{+}$accumulated in the roots.

Bioaccumulation potential was also found by Cantrell \& Linderman (2001), who observed high $\mathrm{Na}^{+}$retention in the roots of inoculated plants, suggesting that $\mathrm{Na}^{+}$can be retained in intra-radicular hyphae or compartmentalized in the vacuoles of the root cells. The translocation factor was less than 1 for all treatments, indicating that the plants could store the $\mathrm{Na}^{+}$ in their roots, i.e., there was no translocation of this element to the aerial part.

Overall, vegetative propagation using $V$. leucocephala cuttings will guarantee the conservation, availability of seedlings, and a more sustainable exploitation of the species. The domestication of $V$. leucocephala will not only reduce the pressure resulting from the overexploitation of this resource, but will also aid in preserving its genetic diversity.

\section{Conclusions}

1. The combination of indole-3-butyric acid (IBA) and zinc increased rooting performance and the number of shoots in $V$. leucocephala cuttings.
2. Association with arbuscular mycorrhizal fungi promoted a significant increase in the development and growth of $V$. leucocephala cuttings.

3. Among the evaluated fungal species, the association with G. albida afforded the highest percentage of colonized roots, as well as a higher soil spore density.

\section{Literature Cited}

Abrantes, H. F. L.; Agra, M. de F. Estudo etnomedicinal das Boraginaceae na caatinga paraibana, Brasil. Revista Brasileira de Farmácia, v.85, p.7-12, 2004.

Amri, E. Influence of arbuscular mycorrhizal fungi on rooting ability of auxin treated stem cuttings of Dalbergia melanoxylon (Guill and Perr.). Research Journal of Botany, v.10, p.88-97, 2015. https://doi. org/10.3923/rjb.2015.88.97

AOAC - Association of Official Analytical Chemists. Official methods of analysis. 15.ed. Washington: AOAC, 1990. 1298p.

Baethgen, W. E.; Alley, M. M. A manual colorimetric procedure for measuring ammonium nitrogen in soil and plant Kjeldahl digests. Communications in Soil Science and Plant Analysis, v.20, p.961969, 1989. https://doi.org/10.1080/00103628909368129

Balota, E. L.; Machineski, O.; Stenzel, N. M. C. Resposta da acerola à inoculação de fungos micorrízicos arbusculares em solo com diferentes níveis de fósforo. Bragantia, v.70, p.166-175, 2011. https://doi.org/10.1590/S0006-87052011000100023

Cantrell, I. C.; Linderman, R. G. Preinoculation of lettuce and onion with VA mycorrhizal fungi reduces deleterious effects of soil salinity. Plant and Soil, v.233, p.269-281, 2001. https://doi. org/10.1023/A:1010564013601

Castro, A. S.; Cavalcante, A. Flores da Caatinga. Campina Grande: Instituto Nacional do Semiárido, 2011. 59p.

EMBRAPA - Empresa Brasileira de Pesquisa Agropecuária. Manual de métodos de análise de solo. 2.ed. Rio de Janeiro: Embrapa Solos, 1997. 212p.

EMBRAPA - Empresa Brasileira de Pesquisa Agropecuária. Métodos de análise de tecidos vegetais utilizados na Embrapa Solos. Rio de Janeiro: Embrapa Solos, 2000. 41p.

Etemadi, M.; Gutjahr, C.; Couzigoou, J. M.; Zouine, M.; Lauressergues, D.; Timmers, A.; Audran, C.; Bouzayen, M.; Bécard, G.; Combier, J. P. Auxin perception is required for arbuscule development in arbuscular mycorrhizal symbiosis. Plant Physiology, v.166, p.281292, 2014. https://doi.org/10.1104/pp.114.246595

Gerdemann, J. W.; Nicolson, T. H. Spores of mycorrhizal endogone species extracted from soil by wet sieving and decanting. Transactions of British Mycological Society, v.46, p.235-244, 1963. https://doi.org/10.1016/S0007-1536(63)80079-0

Giovanetti, M.; Mosse, B. An evaluation of techniques for measuring vesicular arbuscular mycorrhizal infection in roots. New Phytologist, v.84, p.489-500, 1980. https://doi. org/10.1111/j.1469-8137.1980.tb04556.x

Hartmann, H. T.; Kester, D. T.; Davies, J. R.; Geneve, R. L. Plant propagation: Principles and practices. New Jersey: Prentice Hall, 2011.915p.

Hodge, A.; Fitter, A. H. Substantial nitrogen acquisition by arbuscular mycorrhizal fungi from organic material has implications for $\mathrm{N}$ cycling. Proceedings of the National Academy of Sciences, v.107, p.13754-13759, 2010. https://doi.org/10.1073/pnas.1005874107 
Hodge, A.; Storer, K. Arbuscular mycorrhiza and nitrogen: Implications for individual plants through to ecosystems. Plant Soil, v.386, p.1-19, 2014.

Jenkins, W. R. A rapid centrifugal flotation technique for separating nematodes from soil. New Brunswick: Rutgers University, 1964. 692p.

Johansen, A.; Jakobsen, I.; Jensen, E. S. Hyphal N transport by a vesicular-arbuscular mycorrhizal fungus associated with cucumber grown at 3 nitrogen levels. Plant and Soil, v.160, p.1-9, 1994. https://doi.org/10.1007/BF00150340

Maciel, B. A. Unidades de conservação no bioma Caatinga. In: Gariglio, M. A.; Sampaio, E. V. S. B.; Cestaro, L. M.; Kageyama, P. Y. Uso sustentável e conservação dos recursos florestais da Caatinga. Brasília: Serviço Florestal Brasileiro, 2010. Cap.1, p.76-81.

Malibari, A. A.; Fassi, F. A.; Ramadan, E. M. Incidence and infectivity of vesicular-arbuscular mycorrhizas in some Saudi soils. Plant and Soil, v.122, p.105-111, 1988. https://doi.org/10.1007/BF02181759

Marinho Filho, J. D.; Bezerra, D. P.; Araújo, A. J.; Montenegro, R. C.; Pessoa, C.; Diniz, J. C.; Viana, F. A.; Pessoa, O. D.; Silveira, E. R.; Moraes, M. O.; Costa-Lotufo, L. V. Oxidative stress induction by $(+)$-cordiaquinone $\mathrm{J}$ triggers both mitochondria-dependent apoptosis and necrosis in leukemia cells. Chemico-Biological Interactions, v.183, p.369-379, 2010. https://doi.org/10.1016/j. cbi.2009.11.030

Melo, J. I. M. de. Synopsis of Boraginaceae sensu lato in the Caatingas of the São Francisco River, Northeastern Brazil. Anales del Jardín Botánico de Madrid, v.72, p.1-8, 2015.

Milléo, M. V. R.; Cristófoli, I. Resposta da cultura da soja (Glycine max L. Merril) à aplicação de acetato de zinco amoniacal via semente. Scientia Agraria, v.16, p.1-16, 2015.

Oliveira, P. T. F.; Alves, G. D.; Silva, F. A.; Silva, F. S. B. Foliar bioactive compounds in Amburana cearenses (Allemao) A.C. Smith seedlings: Increase of biosynthesis using mycorrhizal technology. Journal of Medicinal Plants Research, v.9, p.712-718, 2015. https:// doi.org/10.5897/JMPR2015.5798

Pacholczak, A.; Petelewicz, P.; Jagiełło, K. K.; Ilczuk, A. Physiological aspects in propagation of smoke tree (Cotinus coggygria Scop. 'royal purple') by stem cuttings. Acta Scientiarum. Polonorum, v.14, p.145-157, 2015.
Phillips, J. M.; Hayman, D. S. Improved procedures for clearing of roots and staining parasitic and vesicular-arbuscular mycorrhizal fungi for rapid assessment of infection. Transactions of British Mycological Society, v.55, p.158-161, 1970. https://doi. org/10.1016/S0007-1536(70)80110-3

Planchette, C.; Fortin, J. A.; Furlan, V. Growth responses of several plant species to mycorrhizae in a soil of moderate P-fertility mycorrhizal dependency under field conditions. Plant and Soil, v.70, p.199-209, 1983. https://doi.org/10.1007/BF02374780

Plank, C. O. Plant analysis reference procedures for the Southern region of the United States: Southern cooperative series bulletin. Georgia: Universidad of Georgia, 1992. 368p.

Sheng, M.; Tang, M.; Chen, H.; Yang, B.; Zhang, F.; Huang, Y. Influence of arbuscular mycorrhizae on photosynthesis and water status of maize plants under salt stress. Mycorrhiza, v.18, p.287-296, 2008. https://doi.org/10.1007/s00572-008-0180-7

Silva, F. A. S.; Fereira, M. R. A.; Soares, L. A. L.; Sampaio, E. V. S. B.; Silva, F. S. B.; Maia, L. C. Arbuscular mycorrihal fungi increase galic acid prodution in leaves of field grown Libidibia férrea. Journal of Medicinal Plant Research, v.8, p.1110-1115, 2014. https://doi.org/10.5897/JMPR2013.5503

Sugai, M. A. A.; Collier, L. S.; Saggin Junior, O. J. Inoculação micorrízica no crescimento de mudas de angico em solo de cerrado. Bragantia, v.70, p.416-423, 2011. https://doi.org/10.1590/ S0006-87052011000200024

Talaat, N. B.; Shawky, B. T. Influence of arbuscular mycorrhizae on yield, nutrients, organic solutes, and antioxidant enzymes of two wheat cultivars under salt stress. Journal of Plant Nutrition and Soil Science, v.174, p.283-291, 2011. https://doi.org/10.1002/ jpln.201000051

Yang, Y.; Tang, M.; Sulpice, R.; Chen, H.; Tian, S.; Ban, Y. Arbuscular mycorrhizal fungi alter fractal dimension characteristics of Robinia pseudoacacia L. seedlings through regulating plant growth, leaf water status, photosynthesis, and nutrient concentration under drought stress. Journal of Plant Growth Regulation, v.33, p.612625, 2014. https://doi.org/10.1007/s00344-013-9410-0 